\title{
ÇEVRESEL İZLEME PROGRAMI: GIDA ENDÜSTRİSİNDE MİKROBİYOLOJIIK GÜVENLİĞİ DESTEKLEYEN ERKEN UYARI SİSTEMİ
}

\author{
Elif Onbaş1 ${ }^{*}$, Aycan Cinar \\ Bursa Teknik Üniversitesi, Mühendislik ve Doğa Bilimleri Fakültesi, Gıda Mühendisliği Bölümü, Bursa, Türkiye \\ Geliş / Received: 20.07.2021; Kabul / Accepted: 29.09.2021; Online bask1 / Published online: 09.10.2021 \\ Onbaşı, E., Cinar, A. (2021). Çevresel izleme programı: Gıda endüstrisinde mikrobiyolojik güvenliği \\ destekleyen erken uyar1 sistemi. GIDA (2021) 46 (5) 1313-1330 doi: 10.15237/gida. GD21105 \\ Onbaş1, E., Cinar, A. (2021). Environmental monitoring program: An early warning system supporting \\ microbiological safety in the food industry. GIDA (2021) 46 (5) 1313-1330 doi: 10.15237/gida. \\ GD21105
}

ÖZ

Günümüzde, birçok ülkede gida güvenliği sistemleri ve yasal zorunluluklar uygulanmasına rağmen gida kaynaklı hastalık ve salgınlar milyonlarca insanı etkilemeye ve binlercesinin ölümüne sebep olmaya devam etmektedir. Gıda kaynaklı hastalıklar ayrıca büyük ölçekli geri çağırmalara, pazar talebinin azalmasına ve tüketicilerin gıda ürünlerine olan güveninin kaybolmasına neden olmaktadır. Gıda güvenliği, üretim ortamında bulunan çeşitli patojenik ve bozulmaya sebep olan mikroorganizmaların gıdaya kontaminasyonu yoluyla tehlikeye girmektedir. Mikroorganizmalar genellikle gida ortamına hammadde, hava, su, çalışan personel ve zararlılar yoluyla girmekte ve gıda işleme ortamında hayatta kalıp çoğalabilmektedirler. Hem gıda ürünlerini hem de üretim ortamını mikrobiyolojik olarak izleme kombinasyonu, g1da güvenliğini ve kalitesini sağlamak için kritik öneme sahiptir. Çevresel izleme programı (ÇiP), bir tesisteki genel hijyen uygulamalarının ve kontrol programlarının etkinliğini değerlendirerek, gida ürünlerinin olası mikrobiyel kontaminasyonunu önlemeyi sağlayan bir izleme programıdır. Bu derlemede ÇIP kurulum metodolojisi ve literatürde yer alan mevcut araştırma çalışmaları harmanlanarak gıda sektörü için bilimsel modeller sunulmaktadır.

Anahtar kelimeler: Çevresel İzleme Programı, gıda kaynaklı salgınlar, patojen mikroorganizmalar, gıda güvenliği, gıda geri çekmeleri

\section{ENVIRONMENTAL MONITORING PROGRAM: AN EARLY WARNING SYSTEM SUPPORTING MICROBIOLOGICAL SAFETY IN THE FOOD INDUSTRY}

\begin{abstract}
Nowadays, foodborne outbreaks still affect millions and kill thousands of people despite implementation of food safety management systems and legal obligations in many countries. Foodborne illness also cause large-scale recalls, reduced market demand, and consumers loss of confidence in food products. Food safety and quality are endangered since microbiological contamination by various pathogenic and spoilage microorganisms in production environment. Microorganisms, generally introduced into the food environment through raw materials, pests, air, water, employees, can survive in food processing environments. The combination of microbiological monitoring of both food products and the production environment is critical to ensuring food safety

*Yazışmalardan sorumlu yazar/ Corresponding author

(17): elifdaban@gmail.com

(0: (+90) 2243003740

冝: (+90) 2243003419

Elif Onbaşı; ORCID no: 0000-0002-5169-7392

Aycan Cinar; ORCID no: 0000-0003-2038- 725X
\end{abstract}


and quality. Environmental monitoring program (EMP) is a monitoring program that allows evaluate the effectiveness of general hygiene practices and control programs to prevent possible microbial contamination of food. In this review, scientific models are given for food sector by combination the EMP methodology and existing research studies in literature.

Keywords: Environmental Monitoring Program (EMP), foodborne outbreaks, pathogenic microorganisms, food safety, food recalls.

\section{GİRİ̧̧}

Gıda Güvenliği; gıda kaynaklı zehirlenmeler ve salginlar nedeniyle günden güne artan ve kontrol altına alınamayan küresel bir sorun olarak karşımıza çıkmaktadır. Dünya çapında her yıl yaklaşık 600 milyon kişi gıda kaynaklı hastalık yaşamakta ve bunların 420.000’i ölümle sonuçlanmaktadır (WHO, 2015). Hastalık Kontrol Merkezlerine (CDC) göre ise sadece Amerika Birleşik Devletleri'nde her y1l 48 milyon kişi gıda kaynaklı hastalıklarla enfekte olmakta, bunların 128.000 'i hastaneye kaldirlmakta ve 3000'ü ölümle sonuçlanmaktadır (Oliver, 2019). Gıda kaynaklı hastalıklar; patojenik ve çürükçül bakteriler, virüsler, parazitler ile bulaşıcı olmayan kimyasallar ve toksinlerin de içinde yer aldığ tehlikeler ile kontamine olmuş gidaların tüketiminden kaynaklanmaktadır (Adley ve Ryan, 2016; Hoffmann ve Scallan, 2017). Hastalık Önleme ve Kontrol Merkezi (CDC, 2016), kontamine olmuş gidaların tüketiminin, 250'den fazla değişik gida kaynaklı hastalığa yol açtığını bildirilmiştir. Dünya çapında meydana gelen tüm gıda kaynaklı hastalıkların yaklaşı \% \%1'i bakteriyel kontaminasyon kaynaklı olup Listeria, Escherichia coli, Salmonella ve Campylobacter buna sebep olan öncül türler olarak bilinmektedir (WHO, 2020).

Listeria monocytogenes, insanlarda listeriyoz hastalığına neden olan ve \%20-30 gibi yüksek ölüm oranı sebebiyle popülasyon için riskli olarak görülen en önemli gıda kaynaklı patojenlerdendir (Kâse vd., 2017; Swaminathan ve Gerner-Smidt, 2007). 2012 yllinda İtalya'dan Amerika Birleşik Devletleri'ne ithal edilen pastörize ricotta peyniriyle bağlantıle bir salgında 20 kişinin hastanelik olduğu ve 4'ünün ölümle sonuçlandığ1 bildirilmiştir. Takip numunesi, işleme tesisi ortamından alınan L. monocytogenes izolatlarının, klinik izolatlar ile eşleşen PFGE (Pulsed Field Jel Elektroforezi) modellerine sahip olduğunu ortaya çıkarmış, bu da peynirin işleme tesislerinde kontamine olduğu sonucunu düşündürmüştür (Acciari vd., 2016). Bugüne kadar yaşanan en büyük listeriyoz salgını 2017'de Güney Afrika'da gerçekleşmiş olup vaka sayısı 1060 olarak bildirilmiştir (Smith vd., 2019). Salgının sebebi fabrika üretim ortaminda $L$. monocytogenes suşu ile kontamine olmuş polony adı verilen tüketime hazır işlenmiş et ürünü olarak belirlenmiştir (Thomas vd., 2020). Diğer bir yandan Listeria kadar ciddi bir patojen olan Salmonella ile ilgili de geçmişte benzer birçok salgın yaşanmıştır. 1988 yılında Amerika'da 209 vakanın meydana geldiği ve yulaf gevreği ile ilişkilendirilen bir salgında Salmonella'nın işleme tesisi ortamından geldiği tespit edilmiştir. 10 yıl sonra 2008 'de aynı yerde Salmonella Agona ile kontamine olmuş pirinç gevreğine bağlı yaşanan benzer bir salgında ise 28 salmonelloz vakası yaşanmış olup her iki salgında da rol oynayan suşların aynı alt tipte olduğu belirlenmiştir. Bunların aynı tesiste üretilmiş olmas1 Salmonella Agona' nin bu tesiste en az 10 yıldır hayatta kaldığını düşündürmüştür (Russo vd., 2013). Yakın bir zamanda (2019) Fransa'da yaşanan ve 1 yaşın altında bebeklerin etkilendiği bir salginda ise kök neden $S$. Agona ile kontamine olmuş toz bebek maması olarak tespit edilmiştir. Vakalar tarafindan tüketilen bebek mamasinda geriye dönük yapılan izlenebilirlikte Salmonella kontaminasyonunun kurutma kulesi ile ilişkili olduğu saptanmıştır (Jones vd., 2019). Bu ve bunun gibi birçok gida kaynaklı salgın ve ürün geri çağırmaları incelendiğinde çoğunda kontaminasyon nedeni gida işleme tesislerindeki çevre ve ekipmanla ilişkilendirilmiştir (Beno vd., 2016; Zoellner vd., 2018).

Gıda kaynaklı bir salgınla karşılaşıldığı durumlarda yetkili mercilerin zehirlenmenin kök nedenini bulmaları ve daha fazla sayıda insan etkilenmeden önce önlem almaları gerekmektedir. Bununla birlikte, salginlar sadece bir halk sağlğg sorunu değil, aynı zamanda ürün geri çağırmalara ve büyük ekonomik kayıplara da neden olmaktadır 
(Jung vd., 2021). Geri çağırma ve toplama; kontamine gida tespit edildikten sonra halk1 uyarmak ve salgının yayılmasını önlemek için üreticiler tarafindan ürünün piyasadan toplanmas süreci olarak tanımlanmaktadır (Özdemir, 2018; Jung vd., 2021). Günümüzde g1da şirketlerinin ekonomik kaybının, her bir geri çekme başına yaklaşık ortalama 10 milyar dolar olduğu tahmin edilmektedir (Weigel, 2019). Bunun yan1 sira firmalar ürün, pazar ve tüketici güven kayb1 nedeniyle ciddi ekonomik kayıplar yaşamakta bu durum iflasa ve piyasadan çekilmeye kadar gidebilmektedir. Amerika Birleşik Devletleri Gıda ve İlaç Dairesine (FDA) göre 2021 yilının başından bu zaman kadar olan süreçte 33 farklı gıda markası piyasaya sürdüğü ürünlerde Listeria ve Salmonella kontaminasyon potansiyeli olmas1 sebebiyle ürünlerini geri çekme ve piyasadan toplama karanı almıştır (FDA, 2021).

G1da ürünlerinin mikrobiyel kontaminasyonu, besin zincirinin her adımında meydana gelebilmektedir. Üretim ortamlar1, ya etkin olmayan temizleme prosedür ve yöntemleri ya da üretim sırasında meydana gelen bulaşı nedeniyle ciddi bir kontaminasyon kaynağı olarak karşımıza çıkmaktadır (Zacharski vd., 2018). Gıda işletmelerinde çalışan personel, alet ekipman, ortam havas1, kullanilan su, paketleme materyalleri, duvarlar, yüzeyler vb. gibi birçok faktör kontaminasyon nedenleri arasinda yer almaktadır (Magdovitz vd., 2020). 1998'de Fransa'da yaşanan gıda kaynaklı salgına ilişkin yapılan bir araştırmada, vakalarının \%40'ının ekipman kontaminasyonu ile bağlantılı olduğunu bildirmiştir (Cappitelli vd., 2014). Bu yüzden besin zincirinin güvenli kalabilmesi için tarımsal üretimden son ürüne kadar (tarladan çatala) geçen tüm üretim süreçlerinde gida güvenliğinin etkin bir şekilde sağlanması kritik öneme sahiptir.

Gıda güvenliği ve kalitesi kavramı, dünya çapında sektörel olarak dikkat çekmiş olup bölgesel, ulusal ve uluslararası düzeyde tüm girişimlerin, yasaların ve yönetim sistemlerinin temelini oluşturmuştur. Gıda güvenliği sistemlerinin çıkış noktası olarak kabul edilen HACCP (Hazard Analysis Critical Control Point), g1da üretimi boyunca oluşturabilecek kimyasal, fiziksel, mikrobiyolojik, alerjen tehlikelerinin kontrol edilmesi ve ortadan kaldırılmasını sağlayan sistematik bir araçtır (Fukushima, 2019; Hasnan ve Mohd Ramli, 2020). ISO 9001 Kalite Yönetim Sistemi, GMP (Good Manufacturing Practice) ve HACCP'in türevi olarak ortaya ç1kan ISO 22000, g1da güvenliğini sağlamada uluslararası ortak bir çözüm sistemi olarak geliştirilmiştir (Pangal vd., 2018). Günümüzde, BRC (İngiliz Perakendeciler Birliği Konsorsiyumu), IFS (Uluslararası G1da Standard1), FSSC 22000 (Gıda Güvenliği Yönetim Sistem Sertifikasyonu) modern gida kalitesi ve güvenliği yönetim sistemleridir ancak devam eden gida kaynaklı salginlar bu sistemlerin mikrobiyolojik tehlikeler açısından tek başlarına yeterli olmadıklarını göstermektedir.

Son yıllarda Amerika Birleşik Devletleri Gıda ve İlaç Dairesi (FDA), salgınların en büyük kaynağı olan mikrobiyel tehlikelerin gida işletmelerinde kontrollerinin daha etkin bir şekilde izlenmesi için HACCP tabanlı gida güvenliği sistemlerine ek olarak iyi tasarlanmış bir Çevresel İzleme Programının (Çİ) uygulaması ve sürdürülmesi önermektedir (FDA, 2015). 2004 yllinda Kanada'da, 2005 yilında Avrupa Birliği'nde, 2006 ve 2020 yillarında Yeni Zelanda'da ve 2011 yillnda Amerika Birleşik Devletleri'nde gida güvenliği ve hijyen programlarına ÇİP dahil edilerek gıda güvenliği konularındaki düzenlemeler güçlendirilmiştir (FIL-IDF, 2020). ÇİP genel hijyen-sanitasyon uygulamalarının ve kontrol programlarının etkinliğini doğrulayan ve gıdalarda olas1 mikrobiyel kontaminasyon noktalarının saptanmasını sağlayan bir izleme programıdır (United Fresh Produce Association, 2018; 3M ve Cornell University, 2019).

Proaktif bir yaklaşım sağlayan Çì sistemi gıda kontaminasyonunu önlemek için nihai ürün kontrolleriyle birlikte bir erken uyarı göstergesi olarak kullanilabilmektedir (FIL-IDF, 2020). Gida işletmelerinde yalnızca son ürünün mikrobiyolojik olarak test edilmesi gida güvenliğini garanti etmek için yeterli olmayabilmektedir çünkü mikroorganizmaların analiz edilen örnek numunede bulunmaması tüm üretimde yok olduğu anlamına gelmemektedir (ANSES, 2020). $\mathrm{Bu}$ nedenle, ÇंP sisteminin işletmelere 
entegrasyonu ile sadece son ürün değil tüm üretim ortamları mikrobiyolojik açıdan değerlendirilip ve rutin olarak takip edilecek böylelikle gida güvenliğinin mikrobiyolojik açıdan tam sağlanmasına imkân sunacaktır (Muhterem-Uyar vd., 2015).

Günümüzde ÇIP sisteminin gida sanayinde uygulanmasını desteklemek amaciyla bazı yönergeler (örn. Almond Board of California, 2009; FDA, 2017; National Fisheries Institute, 2018; 3M ve Cornell Üniversitesi, 2019) ve standartlar (örn. ISO 18593:2018, EN 17141:2020) oluşturulmuştur. $\mathrm{Bu}$ kaynaklarda metodoloji açıkça anlatılmış olmasına rağmen, her işletmenin uygulaması büyük ölçüde işleme tesisinin özelliklerine, patojen ile indikatör mikroorganizma çeşitlerine ve risk faktörlerine göre değişmektedir. ÇİP sistem kurulumundaki en önemli adım üretilen g1da ürünü ve üretim tesisi ile ilgili tehlikelerin ve risklerin göz önünde bulundurulması ve verimli bir uygulama yapilması için stratejiler oluşturulmasıdır. İșletmenin en az 6 aylık geçmiş analiz verileri incelenerek risk değerlendirmesi yapılmalı; numune alma bölgeleri, analizlerin kapsamı ve sıklığ1 bu kapsamda belirlenmelidir. ÇİP sistemleri çeşitli faktörlere bağlı olarak; proses, değişen müşteri ve mevzuat gereksinimleri, üretim tesislerinin tasarımı ve mevsimsel değişiklikler gibi geçici veya kalıc1 değişimlere karşı uygunluğunun garanti altına alınabilmesi için düzenli olarak gözden geçirilmesi ve güncellenmesi gerekmektedir (Cinar ve Onbaş1, 2021). Bu sistemi etkin olarak uygulayan g1da üreticileri, piyasaya sürdükleri ürünlerin üretildiği üretim ortamında potansiyel zararlı sağlık etkilerine yol açabilecek herhangi pozitif kontaminasyon sonucunu yetkili makamlara bildirmeleri gerekmektedir (FDA, 2017).

Son yıllarda dünya çapında ve ülkemizde gıda sektöründe ÇIP sistem kurulum ve uygulamaları artmış olmasına rağmen doğru metodoloji ve uygulamalı örneklerin literatürde az olması nedeniyle gida sanayinde etkin olmayan uygulamalar mevcuttur. Bu ihtiyaçtan hareketle mevcut derleme çalışmasının temel amacı literatürde yer alan rehberlerin ve güncel çalışma örneklerinin 1şığında ÇİP sistem kurulumu için bilimsel uygulama modelleri sağlamaktadır.

\section{YÖNTEMLER}

ÇİP programını uygulamak, işletmeler için ilk başta karışı bir durum olarak görülse bile sistematik bir yaklaşımın kullanılmasıyla oldukça kısa bir sürede etkili bir program geliştirilebilmektedir. ÇIP kurulumunun uygulanacak işletme ve ürün bazında Şekil 1'de verilen akış şeması kullanılarak yapılması önerilmektedir (United Fresh Produce Association EMP Guide, 2018).

- ÇİP takımının oluşturulması

\begin{tabular}{|l|l|}
\hline 1 & C ÇIP takımının oluşturulması \\
\hline 2 & $\begin{array}{l}\text { - Bölgelerin ve numune alma yerlerinin } \\
\text { belirlenmesi }\end{array}$ \\
\hline 3 & - Hedef mikroorganizmaların belirlenmesi \\
\hline 5 & - Analiz planının oluşturulması \\
\hline & $\begin{array}{l}\text { Analiz metodunun belirlenmesi, analizlerin } \\
\text { yapilması ve raporlanması }\end{array}$ \\
\hline & $\begin{array}{l}\text { - Düzeltici ve önleyici faaliyetlerin } \\
\text { belirlenmesi }\end{array}$ \\
\hline
\end{tabular}

Şekil 1. ÇİP programı kurulum şeması 


\section{ÇİP takımının oluşturulması}

ÇIP' in ilk adımı, işletmede yaşanabilecek biyolojik tehlikelerin farkında olan, hijyensanitasyon ve gida güvenliği konusunda deneyime sahip olan personelin bir araya getirilmesidir. İşletmede, ÇIP programının geliştirilmesi ve uygulanması konusunda deneyimli veya eğitim almış bir gida güvenliği uzmanı bulunmuyor ise bu konuda rehberlik almak veya bir süreç yetkilisinden yararlanmak sistemin doğru kurulumu açısından önemlidir (Almond Board of California, 2009). ÇIP ekibi; HACPP takımında da aktif yer alan kalite kontrol sorumlusu (gida mikrobiyolojisi bilgi ve tecrübesine sahip), üretim şefi, bakım sorumlusu, hat operatörü ve temizlik ekibinden oluşabilmektedir. Çï program kurulumuna geçilmeden önce personele program içeriği ve amacı hakkında detaylı bir eğitim verilmesi gerekmektedir. Program çıtılarının raporlanmasi, uygun olmayan durumlarin değerlendirilmesi ve düzeltici faaliyetlerin belirlenmesi durumlarında bu takımın aktif olarak toplanmasi gerekmektedir.

\begin{abstract}
Bölgelerin ve numune alma yerlerinin belirlenmesi

ÇİP ekibi oluşturulduktan sonra, süreç akışını anlamak ve olası kontaminasyon noktalannı belirlemek için üretilen ürünlerin akış şemalarının ele alınarak üretim alanında keşif yürüyüşüne çıkılması gerekmektedir. Program konsepti kapsamında üretim ortamı, kontaminasyona neden olabilecek en yüksek riskli alanlardan (Bölge 1), en düşük riskli alanlara kadar (Bölge 4) dört bölgeye ayrilmalıdır.
\end{abstract}

Bölge 1; ürün paketlenmeden önce ve 1 sıl işlem gibi faaliyetlerden geçtikten sonra gida ile doğrudan temas eden yüzeyler olarak tanımlanmaktadır. Bölge 1 yüzey örnekleri; konveyör bantlar ve kovalar, kaplar, çalışanın elleri (ürüne dokunuyorsa), dilimleyiciler, ürün hazneleri, paketleme makineleri, ambalaj materyalleri vb. (Şekil 2).

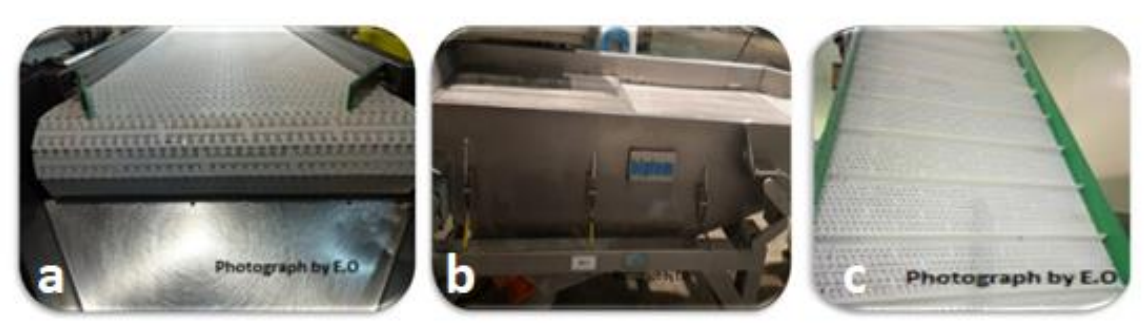

Şekil 2. a: Sarsak elek, b: Ayıklama bandı, c: Taşıyıcı bant

Bölge 2; fiziksel olarak gidaya oldukça yakın fakat ürüne doğrudan temas etmeyen yüzeyler olarak kabul edilmektedir. Bölge 2 yüzey örnekleri; iş kıyafeti, tartı terazileri, pişirme ocakları, kontrol panelleri ve düğmeler, bilgisayar ekranlan, lambalar vb. (Şekil 3).
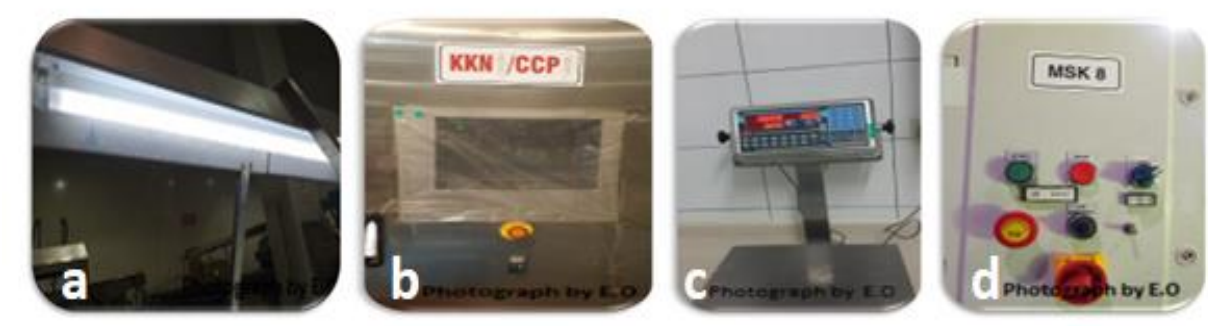

Şekil 3. a: Ayıklama bant lambası, b: Bilgisayar ekranı, c: Terazi, d: Panel butonu 
Bölge 3; Üründen uzakta fakat hala üretim ortaminda olan, dolayli temas ile tehlike yaratabilecek yüzeyler (duvarlar, kapılar, yerler, çöp kutuları vb.) bu bölge kapsamında değerlendirilmektedir (Şekil 4).

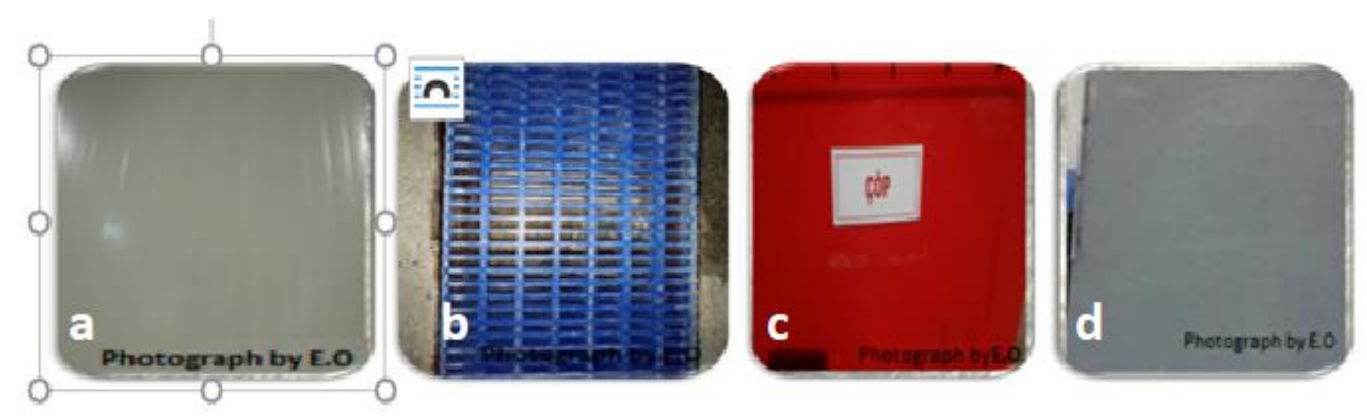

Şekil 4. a: Duvarlar, b: Drenajlar, c: Çöp kutuları, d: Plastik paletler

Bölge 4; En düşük riskli alan olarak bilinen üretim dışı yüzeyler (soyunma odaları, ofisler, yemekhane vb.) olarak sistemde yerini almaktadır (Şekil 5)
(United Fresh Produce Association, 2018; Simmons ve Wiedmann, 2017).
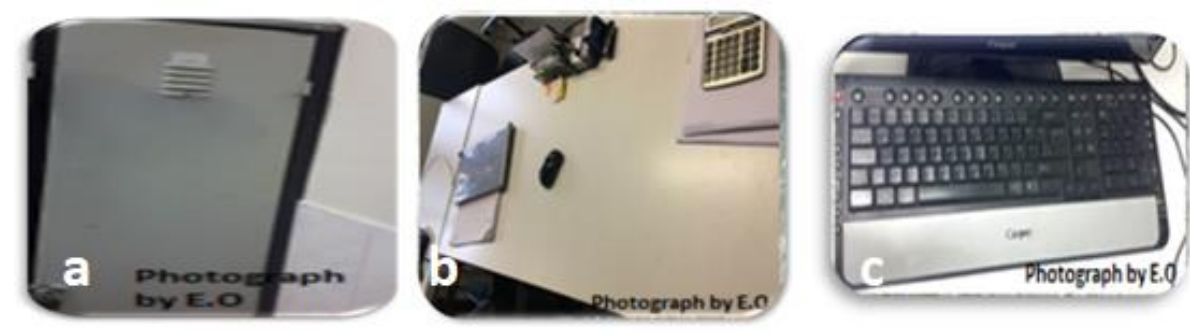

Şekil 5. A: Personel dolapları, b: Çalışma masaları, c: Bilgisayar klavyesi

Son ylllarda dondurulmuş meyve sebze işletmesinde uygulamalı olarak yapılan bir ÇIP çalışmasında Bölge 1'den Bölge 4'e kadar olan 43 örnekleme noktasina ait liste Çizelge 1'de yer almaktadır. Çalışmada, numune alınacak noktaların risk faktörüne göre belirlendiği bildirilmiştir (Cinar ve Onbaş1, 2021).

Simmons ve Wiedmann (2018), Listeria monocytogenes için patojen çevresel izleme programları numune alma yerlerinin tanımlanmas1 ve sınıflandırlması üzerine yapmıs oldukları bir çalışmada mevcut literatür ve kılavuz belgelere dayalı olarak Bölge 1'den 4'e kadar 77 örnekleme noktası listelemişlerdir. Bu kapsamlı çalışmada 16 gıda güvenliği uzmanının görüşleri yer almakta olup, gıda endüstrisi için ÇIP programlarının geliştirilmesine veya iyileştirilmesine yardımcı olacak referans bölgeler bulunmaktadır. Çizelge 2'de bu noktaların özetini içeren liste yer almaktadır.

Gıda üretim tesislerinde farklı ortamlar ve ekipmanlar bulunmasına rağmen yukarıda yer alan çalışmalar gıda endüstrisi tarafindan ÇIP programı kurulurken numune alma ve bölgelere ayırma adımında kullanılabilecek temel bilgileri sağlamaktadır.

\section{Hedef mikroorganizmaların ve limitlerinin belirlenmesi}

Hedef mikroorganizmalar belirlenirken; ürünün yapıs1, üretim ortamı, son yllarda yapılan son ürün ve yüzey alanları mikrobiyoloji analiz sonuçları, müşteri şikayetleri, yasal zorunluluklar gibi parametrelerin üretilen ürün bazında detaylı 
olarak incelenmesi gerekmektedir (Onbaş1, 2020). Hedeflenen mikroorganizmalar indikatör ve patojen mikroorganizmalar olarak iki grupta sınıflandırılabilmektedir. İndikatör mikroorganizmalar, gıdaların işlenmesi sırasında veya sonrasinda meydana gelmiş hata ve kontaminasyonları, işletmenin genel hijyen ve sanitasyon durumunu ve önemli sağllk risklerine neden olabilecek patojenlerin potansiyel varllğını gösteren mikroorganizmalardır (Onmaz vd., 2016). Bu mikroorganizmalar çevresel izlemede hızlı yöntemlerle tespit edilebilmekte olup gidanın bozulabilir doğası nedeniyle gıda endüstrisi için önemlidir ayrıca türe özel testlerin gerekli olup olmadığını belirlemede yardımcı olur (Jemmi ve Stephan, 2006). Toplam mezofilik aerobik bakteri (TMAB), toplam koliformlar, fekal koliformlar ve Enterococcus spp. mikroorganizmaları hijyenik koşulları izlemek için kullanılabilecek bazı indikatör mikroorganizmalara örnek olarak verilmektedir (Channaiah, 2013; Chapin vd.,
2014). Diğer yandan patojen mikroorganizmalar doğada yayın olarak bulunmakla birlikte kontaminasyonu sonucu gida kaynaklı hastalıklara ve zehirlenmelere neden olmaktadirlar (Mazaheri vd., 2021). L. monocytogenes dünyada çapında patojen mikroorganizmalar arasında en çok bilinen ve gida zehirlenmelerinde \%15.6'ya varan yüksek ölüm oranına sahip olan mikroorganizma türüdür (EFSA, 2019). Yüksek öneme sahip bir diğer patojen ise Salmonella spp. klasik olarak genellikle fekal yolla bulaşan bir patojen olarak düşünülse de, kuru gıda işleme tesislerinde en az 10 yıl boyunca varllğını sürdürdügünü gösteren tespitler bulunmaktadır (Beno vd., 2016). Patojen izleme programlarının (özellikle Listeria için) oluşturulması ve uygulanmasında rehberlik etmesi için bir dizi sektöre ve organizasyonlara göre hazırlanmış kılavuz bilgiler Çizelge 3'te yer almaktadır.

Çizelge 1. Her bir bölge için ÇİP numune alma noktaları (Cinar ve Onbaşı, 2021).

\begin{tabular}{llll}
\hline Bölge 1 & Bölge 2 & Bölge 3 & Bölge 4 \\
\hline Personel Elleri & Personel Üniformaları & Metal Dedektörler & Soyunma Odaları \\
\hline Paketleme Makinası & Tartım Terazileri & Soğuk Depolama Odaları & Yemekhane \\
\hline Paketleme Materyalleri & Bakım Ekipmanları & Yerler, Yüzeyler & Tuvaletler \\
\hline Taşıma Elavatörleri & Lambalar & Duvarlar & Koridorlar \\
\hline Sorteks Ayıklama & Karton Kutular & Kapılar & Ofisler \\
\hline Makinesi & Makine Butonları & Drenajlar & Bakım Odaları \\
\hline Taşıma Bantları & Ekipman Çerçeveleri & UV sinek tutucular & \\
\hline Sarsak Elekler & IQF Ekranı & Camlar & \\
\hline Kesim Makineleri & Sorteks Ekran ve & Paletler & \\
\hline Haşlama Makinesi & & Çöp kutuları & \\
\hline Birincil Ambalajlar & & Paspaslar & \\
\hline Termometreler & & Transpaletler & \\
\hline Hava & & Forkliftler & Havalandırmalar \\
\hline Su & & & \\
\hline
\end{tabular}


Çizelge 2. Numune alma noktalarının sınıflandırılması (Simmons ve Wiedmann, 2018)

\begin{tabular}{|c|c|c|c|}
\hline Numune Noktasi & Tanım ve Yorum & Tesisin Türü & ÇİP Bölgesi \\
\hline Yuvarlak Öğ̈̈tücüler & $\begin{array}{l}\text { Öğütücü kaselerin iç kısımları, } \\
\text { bıçaklar ve diğer temizlenmesi zor } \\
\text { temas alanlarına özellikle dikkat } \\
\text { edilmelidir. }\end{array}$ & Et ve Deniz ürünleri & Bölge 1 \\
\hline $\begin{array}{l}\text { Bitmiş ürün için kullanılan } \\
\text { kesme tahtaları }\end{array}$ & $\begin{array}{l}\text { Hasarlı ve/veya temizlenmesi zor } \\
\text { alanlara özel dikkat gösterilmelidir. }\end{array}$ & $\begin{array}{l}\text { Et, deniz ürünleri, süt } \\
\text { ürünleri, perakende }\end{array}$ & Bölge 1 \\
\hline Karıştırıc1/ Öğütücüler & $\begin{array}{l}\text { Bıçaklar ve diğer temizlenmesi zor } \\
\text { temas alanlarına özellikle dikkat } \\
\text { edilmelidir. }\end{array}$ & Et ve deniz ürünleri & Bölge 1 \\
\hline $\begin{array}{l}\text { Ürünle Temas eden diğer } \\
\text { ekipmanlar (örn. fiçllar, } \\
\text { tanklar, masalar) }\end{array}$ & & $\begin{array}{l}\text { Et, deniz ürünleri, süt } \\
\text { ürünleri }\end{array}$ & Bölge 1 \\
\hline $\begin{array}{l}\text { Firçalar ve son ürüne temas } \\
\text { eden diğer ekipmanlar }\end{array}$ & $\begin{array}{l}\text { Örneğin; peynirin olgunlaşması } \\
\text { sırasında tuzlu su ve ürün ile temas } \\
\text { eden firçalar. }\end{array}$ & Süt ürünleri & Bölge 1 \\
\hline Dilimleyici/soyucu/doğrayıc1 & $\begin{array}{l}\text { G1da ile temas eden ve hijyenik } \\
\text { tasarım hataları bulunan (örn. } \\
\text { bıçaklar, konveyör bant) noktalara } \\
\text { dikkat edilmelidir. }\end{array}$ & $\begin{array}{l}\text { Et, deniz ürünleri, süt } \\
\text { ürünleri, perakende } \\
\text { üretim. }\end{array}$ & Bölge 1 \\
\hline $\begin{array}{l}\text { Bitmiş ürün ile temas eden } \\
\text { korumalıklar (örn. seçme ve } \\
\text { ayıklama bantları). }\end{array}$ & & $\begin{array}{l}\text { Tüm g1da üretim } \\
\text { yerleri }\end{array}$ & Bölge 1, Bölge 2 \\
\hline $\begin{array}{l}\text { Konveyör taşıma bant ve } \\
\text { sistemleri, gida ile temas eden } \\
\text { diğer taşıma sistemleri. }\end{array}$ & $\begin{array}{l}\text { Numune almadan önce sistem en } \\
\text { az } 15 \text { dakika çalıştırılmalı; içi boş } \\
\text { silindirler, kumaş destekli kayışlar, } \\
\text { metal bağlantılar ve etiketler gibi } \\
\text { temizlenmesi zor alanlara özel } \\
\text { dikkat gösterilmelidir. }\end{array}$ & Et, deniz ürünleri & Bölge 1 \\
\hline Paketleme makineleri & $\begin{array}{l}\text { Ürünle temas eden noktalara } \\
\text { Özellikle dikkat edilmeli. }\end{array}$ & $\begin{array}{l}\text { Et, deniz ürünleri, süt } \\
\text { ürünleri, tüm g1da } \\
\text { üretimleri }\end{array}$ & Bölge 1, Bölge 2 \\
\hline $\begin{array}{l}\text { Bitmiş ürünlerin taşındığı } \\
\text { boru ve tüplerin iç kısımları }\end{array}$ & $\begin{array}{l}\text { Gıda temas yüzeyleri, contalar, } \\
\text { çıkmaz noktalar, bağlantılar, süt } \\
\text { taş1 biriken veya -biyofilm oluşumu } \\
\text { olan alanlara dikkat edilmelidir. }\end{array}$ & Süt Ürünleri & Bölge 1 \\
\hline $\begin{array}{l}\text { Bitmiş ürün saklama fiç1/ } \\
\text { tank, depolama ekipmanlar1 }\end{array}$ & & Deniz Ürünleri & Bölge 1 \\
\hline $\begin{array}{l}\text { Bitmiş ürünlerle temas eden } \\
\text { kovalar/kutular }\end{array}$ & $\begin{array}{l}\text { Ürünleri sslatmak/durulamak için } \\
\text { kullanılan kovanın iç kısmına özel } \\
\text { dikkat gösterilmesi gerekmektedir. }\end{array}$ & $\begin{array}{l}\text { Deniz Ürünleri, Tüm } \\
\text { üretimler }\end{array}$ & Bölge 1 \\
\hline Dolum Üniteleri & $\begin{array}{l}\text { Ağız kısımlarına, kapak contalarına } \\
\text { ve diğer kauçuk parçalar ile } \\
\text { temizlenmesi zor gida ile temas } \\
\text { eden alanlara dikkat edilmelidir. }\end{array}$ & Et ve süt ürünleri & Bölge 1 \\
\hline Gida ile temas eden teraziler & & Tüm üretimler & Bölge 1 \\
\hline Vanalar & $\begin{array}{l}\text { Temizlenmesi zor alanlara özel } \\
\text { dikkat gösterilmelidir. }\end{array}$ & Süt ürünleri & Bölge 1 \\
\hline
\end{tabular}


Çizelge 2. devam

\begin{tabular}{|c|c|c|c|}
\hline Numune Noktas1 & Tanim ve Yorum & Tesisin Türü & ÇİP Bölgesi \\
\hline Bitmiş ürün kasaları & $\begin{array}{l}\text { Hasarli ve hijyenik açidan } \\
\text { temizlemeye uygun olmayan } \\
\text { kasalara dikkat edilmelidir. }\end{array}$ & $\begin{array}{l}\text { Süt } \quad \text { ürünleri, } \\
\text { Perakende ürünler }\end{array}$ & Bölge 1 \\
\hline Vakum Makinaları & $\begin{array}{l}\text { Hazneler ve mühürleme } \\
\text { noktalarına dikkat edilmelidir. }\end{array}$ & $\begin{array}{l}\text { Et ve süt ürünleri, } \\
\text { Üretimler }\end{array}$ & Bölge 1, Bölge 2 \\
\hline $\begin{array}{l}\text { Bitmiş ürün ile temas eden } \\
\text { termometreler }\end{array}$ & & $\begin{array}{l}\text { Et, deniz ürünleri, süt } \\
\text { ürünleri, perakende } \\
\text { tüm üretimler }\end{array}$ & Bölge 1 \\
\hline $\begin{array}{l}\text { Bitmiş ürünle temas eden } \\
\text { önlükler }\end{array}$ & $\begin{array}{l}\text { Yeniden kullanılabilir önlüklere } \\
\text { odaklanın; ön kısımlara, iplere, } \\
\text { aşınmıs ve çok kirli önlüklere, } \\
\text { alttan sarkan ve konveyör ile temas } \\
\text { eden önlüklere özel dikkat } \\
\text { gösterilmelidir. }\end{array}$ & $\begin{array}{l}\text { Et, deniz ürünleri, süt } \\
\text { ürünleri, perakende } \\
\text { tüm üretimler }\end{array}$ & Bölge 1, Bölge 2 \\
\hline Konveyör/Taşıma sistemleri & $\begin{array}{l}\text { Bantların ürün ile temas etmeyen } \\
\text { noktaları. }\end{array}$ & Et, deniz ürünleri & Bölge 2 \\
\hline Bitmiş ürün rafları & $\begin{array}{l}\text { İçi boş parçalar, kapaklar ve } \\
\text { temizlenmesi zor diğer alanlara } \\
\text { dikkat edilmelidir. }\end{array}$ & $\begin{array}{l}\text { Et, deniz ürünleri, süt } \\
\text { ürünleri, perakende }\end{array}$ & Bölge 2, Bölge 1 \\
\hline $\begin{array}{l}\text { Gida üretim ekipmanlarının } \\
\text { gida ile temas etmeyen } \\
\text { çerçeve ve diğer bölümleri. }\end{array}$ & $\begin{array}{l}\text { Çerçeve ve diğer temasta olmayan } \\
\text { yüzeyler } \\
\text { (Örneğin, dilimleyiciler, soyucular, } \\
\text { paketleme ekipmanları, } \\
\text { torbalayıcilar, fiçlar, tanklar, } \\
\text { masalar, elektrik kablolar, vb.). }\end{array}$ & $\begin{array}{l}\text { Et, deniz ürünleri, süt } \\
\text { ürünleri, üretimler }\end{array}$ & Bölge 2, Bölge 3 \\
\hline Bakım araçları & $\begin{array}{l}\text { Bitmiş ürün alanında kullanılan } \\
\text { bakım araçlarına dikkat edilmelidir. }\end{array}$ & $\begin{array}{l}\text { Et, deniz ürünleri, süt } \\
\text { ürünleri, üretimler }\end{array}$ & Bölge 2, Bölge 3 \\
\hline $\begin{array}{l}\text { Ürüne yakın ekipmanların } \\
\text { kontrol düğmeleri/ ekranları }\end{array}$ & $\begin{array}{l}\text { Düğmeler, ekran yüzeyleri ve } \\
\text { temizlenmesi zor diğer alanlara } \\
\text { dikkat edilmelidir. }\end{array}$ & $\begin{array}{l}\text { Et, deniz ürünleri, } \\
\text { üretimler }\end{array}$ & Bölge 2, Bölge 3 \\
\hline Havalandırma fanları & $\begin{array}{l}\text { Yan kanallar, hava girişi, çark odas1 } \\
\text { vb. }\end{array}$ & $\begin{array}{l}\text { Deniz ürünleri, süt } \\
\text { ürünleri, üretimler }\end{array}$ & $\begin{array}{l}\text { Bölge 2, Bölge } \\
\text { 3, Bölge } 1\end{array}$ \\
\hline Teraziler & $\begin{array}{l}\text { Gida ile temas etmeyen, ambalajlı } \\
\text { ürün terazileri vb. }\end{array}$ & $\begin{array}{l}\text { Et, deniz ürünleri, süt } \\
\text { ürünleri, perakende } \\
\text { tüm üretimler }\end{array}$ & Bölge 2, Bölge 3 \\
\hline $\begin{array}{l}\text { Son ürünün bulunduğu } \\
\text { alanda kullanilan perdeler }\end{array}$ & & $\begin{array}{l}\text { Et, deniz ürünleri, süt } \\
\text { ürünleri, perakende } \\
\text { tüm üretimler }\end{array}$ & Bölge 2, Bölge 3 \\
\hline $\begin{array}{lll}\begin{array}{l}\text { Personel } \\
\text { çizmeleri }\end{array} & \text { ayakkabı } & \text { ve } \\
\end{array}$ & $\begin{array}{l}\text { Ayakkabının kenarlarına özellikle } \\
\text { dikkat edilmelidir. }\end{array}$ & $\begin{array}{l}\text { Et, deniz ürünleri, süt } \\
\text { ürünleri, perakende } \\
\text { tüm üretimler }\end{array}$ & Bölge 2, Bölge 3 \\
\hline $\begin{array}{l}\text { Açık bitmiş ürünün yer aldığ } \\
\text { bölgede soğutucu kapıları ve } \\
\text { nakliye için kullanılan diğer } \\
\text { kapılar. }\end{array}$ & $\begin{array}{l}\text { Temizlemesi zor olan kauçuk kap1 } \\
\text { contaları, çatlaklar, aşımış ve } \\
\text { hasarlı alanlara dikkat edilmelidir. }\end{array}$ & $\begin{array}{lr}\text { Et, deniz } & \text { ürünleri, } \\
\text { perakende } & \text { tüm } \\
\text { üretimler } & \end{array}$ & Bölge 2, Bölge 3 \\
\hline Drenajlar & $\begin{array}{l}\text { Kapaklara, çatlaklara } \\
\text { önem verilmelidir. }\end{array}$ & $\begin{array}{l}\text { Et, deniz ürünleri, süt } \\
\text { ürünleri, perakende } \\
\text { tüm üretimler. }\end{array}$ & Bölge 3 \\
\hline
\end{tabular}


Çizelge 2. devam

\begin{tabular}{|c|c|c|c|}
\hline Numune Noktas1 & Tanım ve Yorum & Tesisin Türü & ÇİP Bölgesi \\
\hline Paspaslar & $\begin{array}{l}\text { Mevcut çatlak veya yarıklara dikkat } \\
\text { göstererek alt taraftan numune } \\
\text { alınması önerilmektedir. }\end{array}$ & $\begin{array}{lr}\text { Et, deniz } & \text { ürünleri, } \\
\text { perakende } & \text { tüm } \\
\text { üretimler } & \\
\end{array}$ & Bölge 3, Bölge 2 \\
\hline Yerler, Zeminler & $\begin{array}{l}\text { Su biriken noktalar, çatlaklar ve } \\
\text { temizlenmesi zor alanlara dikkat } \\
\text { edilmelidir. Son ürün alanı yere } \\
\text { yakın zeminler Bölge 2'ye girebilir. } \\
\text { Diğer zeminler Bölge } 3 \text { ve } 4 \text { olarak } \\
\text { tanımlanır. }\end{array}$ & $\begin{array}{l}\text { Et, deniz ürünleri, süt } \\
\text { ürünleri, perakende } \\
\text { tüm üretimler }\end{array}$ & Bölge 3, Bölge 2 \\
\hline Taşıma arabaları & $\begin{array}{l}\text { Raflara, kenarlara, tekerleklere, } \\
\text { oyuklara } \\
\text { ve temizlenmesi zor diğer alanlara } \\
\text { dikkat edilmelidir. }\end{array}$ & $\begin{array}{l}\text { Et, deniz ürünleri, süt } \\
\text { ürünleri, perakende } \\
\text { tüm üretimler }\end{array}$ & Bölge 3 \\
\hline Zemin/duvar bağlantıları & $\begin{array}{l}\text { Gıda ile temas ortamına yakın } \\
\text { zemin-duvar birleşimleri Bölge } 2 \\
\text { olarak tanımlanırken, diğer } \\
\text { bölümlerde yer alanlar Bölge } 3 \text { ve } 4 \\
\text { olarak tanımlanır. }\end{array}$ & $\begin{array}{l}\text { Et, deniz ürünleri, süt } \\
\text { ürünleri, perakende } \\
\text { tüm üretimler }\end{array}$ & Bölge 3 \\
\hline Ayak banyoları & $\begin{array}{l}\text { Ayak banyolarında altta yer alan } \\
\text { çatlak veya yarıklara dikkat } \\
\text { edilmelidir. }\end{array}$ & $\begin{array}{l}\text { Et, deniz ürünleri, süt } \\
\text { ürünleri, perakende } \\
\text { tüm üretimler }\end{array}$ & Bölge 3, Bölge 4 \\
\hline Temizlik ekipmanları & $\begin{array}{llr}\text { Demonte } & \text { olmasi zor } & \text { olan } \\
\text { ekipmanlara } & \text { (silecek, } & \text { paspas, } \\
\text { süngerler) } & \text { özellikle } & \text { dikkat } \\
\text { edilmelidir. } & & \end{array}$ & $\begin{array}{l}\text { Et, deniz ürünleri, süt } \\
\text { ürünleri, perakende } \\
\text { tüm üretimler }\end{array}$ & Bölge 3 \\
\hline Çöp Kutuları & $\begin{array}{l}\text { Çöp kutularının alt kısımlarına, } \\
\text { çatlak alanlar ve diğer temizlenmesi } \\
\text { zor alanlarına dikkat edilmesi } \\
\text { gerekmektedir. Bitmiş ürüne en } \\
\text { yakın çöp kutuları Bölge } 2 \text { veya } 3 \\
\text { olarak tanımlanır. }\end{array}$ & $\begin{array}{l}\text { Et, deniz ürünleri, süt } \\
\text { ürünleri, perakende } \\
\text { tüm üretimler }\end{array}$ & Bölge 3 \\
\hline El yıkama lavaboları & $\begin{array}{l}\text { İç ve diş, özellikle temizlenmesi zor } \\
\text { alanlara önem verilmelidir. }\end{array}$ & $\begin{array}{l}\text { Et, deniz ürünleri, süt } \\
\text { ürünleri, perakende } \\
\text { tüm üretimler }\end{array}$ & Bölge 3 \\
\hline $\begin{array}{l}\text { Arabalar, kaldırıcılar, } \\
\text { forkliftler ve palet krikoları }\end{array}$ & $\begin{array}{l}\text { Raflara, kulplara, tekerleklere, } \\
\text { bıçakları ve alt taraflarına dikkat } \\
\text { edilmelidir. }\end{array}$ & $\begin{array}{l}\text { Et, deniz ürünleri, süt } \\
\text { ürünleri, perakende } \\
\text { tüm üretimler }\end{array}$ & Bölge 3, Bölge 2 \\
\hline Duvarlar & $\begin{array}{l}\text { Gıda ile temas yakınındaki duvarlar } \\
\text { belki } \\
\text { Bölge } 2 \text { olarak sınıflandırılır. Çoğu } \\
\text { duvar örnekleme siteleri Bölge } 3 \\
\text { veya } 4 \text { olacaktır. Çatlaklara ve ıslak } \\
\text { alanlara dikkat edilmelidir. }\end{array}$ & $\begin{array}{l}\text { Et, deniz ürünleri, süt } \\
\text { ürünleri, perakende } \\
\text { tüm üretimler }\end{array}$ & Bölge 3 \\
\hline Tavanlar & $\begin{array}{l}\text { Yoğuşma olan alanlara, çatlaklara } \\
\text { ve temizlenmesi zor diğer noktalar } \\
\text { özel dikkat gösterilmelidir. } \\
\text { Tavanda damlalar varsa ürünle } \\
\text { temas etme potansiyeli olduğu için } \\
\text { Bölge } 2 \text { olarak kabul edilebilir. }\end{array}$ & $\begin{array}{l}\text { Et, deniz ürünleri, süt } \\
\text { ürünleri, perakende } \\
\text { tüm üretimler }\end{array}$ & Bölge 3 \\
\hline
\end{tabular}


Çizelge 2. devam

\begin{tabular}{|c|c|c|c|}
\hline Numune Noktas1 & Tanim ve Yorum & Tesisin Türü & ÇİP Bölgesi \\
\hline Fanlar & $\begin{array}{l}\text { B1çaklara, kapaklara, motorlara ve } \\
\text { temizlenmesi zor alanlara dikkat } \\
\text { edilmelidir. }\end{array}$ & $\begin{array}{l}\text { Et, deniz ürünleri, süt } \\
\text { ürünleri, perakende } \\
\text { tüm üretimler }\end{array}$ & Bölge 3 \\
\hline $\begin{array}{l}\text { Portatif basamaklar / } \\
\text { tabureler/ merdivenler }\end{array}$ & $\begin{array}{l}\text { Eller ve ayakkabiların her ikisinin } \\
\text { de temas kurduğu basamaklara } \\
\text { özel dikkat edilmelidir. }\end{array}$ & $\begin{array}{l}\text { Et, deniz ürünleri, süt } \\
\text { ürünleri, perakende } \\
\text { tüm üretimler }\end{array}$ & Bölge 3 \\
\hline Elektrik prizi kapaklar1 & $\begin{array}{l}\text { Elektrik prizinin etrafindaki ve } \\
\text { içindeki } \\
\text { edilmelidir. }\end{array}$ & $\begin{array}{l}\text { Et, deniz ürünleri, süt } \\
\text { ürünleri, perakende } \\
\text { tüm üretimler }\end{array}$ & Bölge 3, Bölge 4 \\
\hline Sabunluklar & $\begin{array}{lcc}\text { Örnek alan } & \text { olarak dağıtıc1 } \\
\text { üzerindeki } & \text { düğmeler ve ve } \\
\text { temizlemesi zor alanlar alınabilir. }\end{array}$ & $\begin{array}{l}\text { Et, deniz ürünleri, süt } \\
\text { ürünleri, perakende } \\
\text { tüm üretimler }\end{array}$ & Bölge 3, Bölge 4 \\
\hline Personel Soyunma Odaları & $\begin{array}{l}\text { Üretim alanına doğrudan bağlantill } \\
\text { mola ve soyunma odaları, Bölge } 3 \\
\text { olarak kabul edilecektir. }\end{array}$ & $\begin{array}{l}\text { Et, deniz ürünleri, süt } \\
\text { ürünleri, perakende } \\
\text { tüm üretimler }\end{array}$ & Bölge 4, Bölge 3 \\
\hline $\begin{array}{lll}\text { Sevkiyat } & \text { ve } & \text { Yükleme } \\
\text { Noktalar1 } & & \end{array}$ & $\begin{array}{l}\text { Tamponlar ve şerit kapilara dikkat } \\
\text { edilmelidir. }\end{array}$ & $\begin{array}{l}\text { Et, deniz ürünleri, süt } \\
\text { ürünleri, perakende } \\
\text { tüm üretimler. }\end{array}$ & Bölge 4, Bölge 3 \\
\hline Pencereler & $\begin{array}{l}\text { Çatlamış, yoğuşma olmuş ve } \\
\text { temizlenmesi zor yüzeylere dikkat } \\
\text { edilmelidir. }\end{array}$ & $\begin{array}{l}\text { Et, deniz ürünleri, süt } \\
\text { ürünleri, perakende } \\
\text { tüm üretimler }\end{array}$ & Bölge 4, Bölge 3 \\
\hline
\end{tabular}

Çizelge 3. Patojen çevresel izleme programlarının oluşturulmasına yönelik rehber doküman örnekleri (3M \& Cornell University, 2019).

\begin{tabular}{|c|c|c|c|}
\hline Dökümanın Adı & Organizasyon & Hedef Endüstri & Hedef Patojen \\
\hline Süt Patojenleri El Kitab1 & $\begin{array}{l}\text { Süt Ürünleri Güvenliği } \\
\text { Victoria (Avustralya) }\end{array}$ & Süt ve Süt Ürünleri & $\begin{array}{l}\text { Salmonella ve } \\
\text { L. monocytogenes }\end{array}$ \\
\hline $\begin{array}{l}\text { Risk Altındaki Gidalarda } \\
\text { Listeria monocytogenes }\end{array}$ & $\begin{array}{l}\text { Perakende Sanayicileri } \\
\text { Derneği }\end{array}$ & Tüketime Hazır Gıdalar & L. monocytogenes \\
\hline $\begin{array}{lr}\text { Çevresel } & \text { İzleme ve } \\
\text { Düzeltici } & \text { Faaliyetler } \\
\text { Rehberi } & \\
\end{array}$ & & & \\
\hline $\begin{array}{l}\text { Tüketime Hazır G1dalarda } \\
\text { Listeriar monocytogenes'in } \\
\text { kontrolü: Sanayi Rehberi }\end{array}$ & $\begin{array}{ll}\text { Amerika } & \text { Birleşik } \\
\text { Devletleri Gida ve İlaç } \\
\text { Dairesi }\end{array}$ & Tüketime Hazır Gıdalar & L. monocytogenes \\
\hline $\begin{array}{lr}\text { Listeria } & \text { monocytogenes'in } \\
\text { Kontrolü: } & \text { ABD Süt } \\
\text { Ürünleri } & \text { Endüstrisi } \\
\text { Rehberi } & \\
\end{array}$ & $\begin{array}{l}\text { ABD Süt Ürünleri } \\
\text { İnovasyon Merkezi }\end{array}$ & Süt Ürünleri & L. monocytogenes \\
\hline $\begin{array}{l}\text { Taze Ürün Endüstrisi için } \\
\text { Listeria Çevresel İzleme ve } \\
\text { Kontrol Rehberi }\end{array}$ & $\begin{array}{l}\text { ABD Taze Üretim } \\
\text { Ürünleri Derneği }\end{array}$ & Taze Üretim Ürünleri & L. monocytogenes \\
\hline $\begin{array}{l}\text { FSIS Uyum Kilavuzu: Isıl } \\
\text { işlem sonrası Hazır Et ve } \\
\text { Kanatlı Urünlerinde Listeria } \\
\text { monocytogenes'in Kontrolü }\end{array}$ & $\begin{array}{l}\text { ABD Tarım Bakanllğ̆ } \\
\text { Gıda Güvenliği ve } \\
\text { Denetim Servisi }\end{array}$ & Tüketime Hazır Gıdalar & L. monocytogenes \\
\hline
\end{tabular}


Çevresel izleme analiz sonuçları ile ilgili dünya çapında herhangi bir yasal limit bulunmamasına rağmen Avrupa Komisyonu (EC, 2001), temizlik ve sanitasyon sonrasi üretim alanında gida ile temasta olan yüzeyler için 0 ila $10 \mathrm{kob} / \mathrm{cm}^{2}$ arasinda mikrobiyel seviyeler önermiştir. Hedef değerler her tesis ve her ürün türü için değişmekle birlikte her bölge için de (Bölge1-4) farklı olabilmektedir. Özellikle indikatör mikroorganiz- malarda limit oluşturmak için işletmede 6 ila 12 aylık geçmiş verilerin, müşteri şikayetleri ve spesifikasyonlarının incelenmesi gerekmektedir (Channaiah, 2013). Almond Board of California (2009) tarafindan sağlanan 'gida ile temas eden ekipman ve yüzey temizliği için mikrobiyolojik gösterge sınırları' rehberlik sağlaması adına Çizelge 4'te yer almaktadır.

Çizelge 4. Almond Board of California tarafindan sağlanan dezenfektanın uygulanmasından önce ve sonra ekipman temizliği için önerilen mikrobiyolojik gösterge limitleri.

\begin{tabular}{llcc}
\hline $\begin{array}{l}\text { İndikatör } \\
\text { Mikroorganizma }\end{array}$ & $\begin{array}{l}\text { Hedef/Kabul } \\
\text { edilebilir } \\
\text { limitler }\end{array}$ & $\begin{array}{c}\text { Isıl İslem Sonras1 } \\
\text { Dezenfektan Öncesi } \\
\left(\mathrm{kob} / 250 \mathrm{~cm}^{2}\right)\end{array}$ & $\begin{array}{c}\text { Isıl İşlem - } \\
\text { Dezenfektan Sonras1 } \\
\left(\mathrm{kob} / 250 \mathrm{~cm}^{2}\right)\end{array}$ \\
\hline Aerobik Koloni Sayis1 & Hedef & $<100$ & $<10$ \\
& Kabul edilebilir & $<500$ & $<100$ \\
\hline Koliform & Hedef & $<10$ & $<10$ \\
& Kabul edilebilir & $<100$ & $<50$ \\
\hline Toplam & Hedef & $<10$ & $<10$ \\
Enterobacteriaceae & Kabul edilebilir & $<100$ & $<50$ \\
\hline
\end{tabular}

\section{Analiz planının oluşturulması}

Çevresel numunelerin sayısı ve yeri, ürüne ve sürece özgü risk seviyelerine göre belirlenmelidir. Geçmişinde pozitif patojen sonuçları olan, su kullanımı ile hareket trafiğinin fazla olduğu ve mikrobiyolojik olarak hassas hammaddelerin işlendiği veya depolandığı alanlardan daha yüksek siklıkta numune alınmalıdır (3M ve Cornell University, 2019). Numune alma zamanı ise ÇİP'in amacina göre üretim öncesi, ortası veya sonrasinda belirlenebilmekte olup amaç hijyensanitasyon etkinliğini doğrulamaksa, sanitasyon öncesi, sonrası ve üretim öncesi örnekleme işlemi yapılmaktadır. Gıda işleme planındaki bir ekipmanda üretim sürecinde kontaminasyon şüphesi oluştuğunda, ekipman çalışırken numune alınabilmektedir. Bir sanitasyon prosedüründen sonra, dezenfektan kalıntılarının bakteriler üzerindeki etkisini belirlemek için numune alımından önce belirli bir süre beklenmesi ISO 18593: 2018 tarafindan tavsiye edilmiştir (Mota vd., 2021). Almond Board of California'nin Salmonella spp.'yi önlemek için oluşturduğu patojen çevresel izleme programında yer alan analiz planı Çizelge 5'te yer almaktadır. Çizelge 6'da ise AIB (Amerika Firıncilar Enstitüsü) tarafindan yayınlanan ÇiP kılavuzunda yer alan çevresel izleme planı örneği bulunmaktadır (Channaiah, 2013).

Gıda üretim tesisleri, ürünleriyle ilgili mikrobiyel risklerini dikkatli bir şekilde değerlendirdikten sonra, yukarıda yer alan örnek planlara uygun olarak ÇIP planı oluşturması ve her işletme için bu planın özelleștirilmesi önerilmektedir.

\section{Analiz metodunun belirlenmesi, analizlerin} yapılmas1 ve raporlanmas1

ÇİP numunelerinin analizleri için sayısız klasik ve hızlı mikrobiyolojik yöntem mevcuttur. Hangi analiz yöntemi seçilirse seçilsin, kullanılan yöntemin doğrulanması en önemli adımlardan bir tanesidir. Uluslararas1 Standardizasyon Örgütü (ISO) 18593:2018 standard1, gida üretim zincirinde mikrobiyolojik yüzey örneklemesi için kullanılan yatay metotlar ile ilgili bilgi sağlamaktadır. $\mathrm{Bu}$ standart numune alma teknikleri, swap çubukları ve sünger/bez yöntemleri, numune alma yeri, alanı, zamanı ve sıklığ1 açısından numune alma prosedürüne k1lavuzluk etmektedir. Amerika Birleşik Devletleri'nde ise FDA'nın Bakteriyolojik Analitik El Kitabındaki (BAM) yöntemler, analizler için resmi yöntemler olarak kabul edilmektedir. 
Bunlara ilaveten her ülkede yayınlanmış ülkeye ve sektöre özgü yöntemler de bulunmaktadır ancak yukarıda belirtilen yöntemler evrensel olarak tanınmakta ve kabul edilmektedir. Yayınlanmış çoğu standarda göre spesifik mikroorganizmaların tespiti ve mikroorganizma sayılarının belirlenmesi için yaklaşı1 $100 \mathrm{~cm}^{2}$ alandan numune alımı yapilmalidır (Mota vd., 2020).

Çizelge 5. Numune alma yeri örnekleri, mikrobiyolojik test türü, minimum numune alma sıklı̆̆ ve bölgelere göre tipik numune sayısı

\begin{tabular}{|c|c|c|c|c|}
\hline $\begin{array}{l}\text { Bölge } \\
\text { Numaras1 }\end{array}$ & Numune Alma Yeri Örnekleri & Mikrobiyolojik Test & $\begin{array}{l}\text { Minimum } \\
\text { Numune Frekansı }\end{array}$ & $\begin{array}{l}\text { Örnek } \\
\text { Say1s1 }{ }^{1}\end{array}$ \\
\hline 1 & $\begin{array}{l}\text { Doğrudan veya dolaylı ürün } \\
\text { temas yüzeyleri; örneğin tasnif } \\
\text { hatları, ürün konveyörleri, ürün } \\
\text { boşaltma kanalları, boru hattı iç } \\
\text { kısımları, depolama hunileri, } \\
\text { doldurma hunileri, nozullar, ürün } \\
\text { siyırıcılar, mutfak eşyaları, çalışsan } \\
\text { elleri }\end{array}$ & 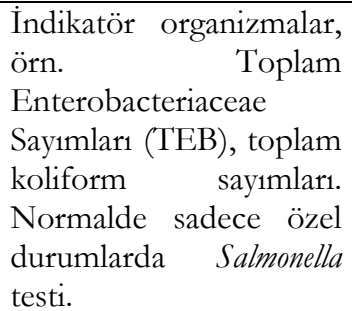 & $\begin{array}{lr}\text { Haftalık } & \text { Temizlik } \\
\text { sonrası, } & \text { Urretim } \\
\text { Öncesi). } & \text { Ayrıca } \\
\text { araştırma } & \text { için } \\
\text { gerektiğinde } & \\
\text { doğrulama } & \text { ve } \\
\text { onaylama } & \text { için } \\
\text { numune alımı. }\end{array}$ & $\begin{array}{l}\text { Üretim } \\
\text { hatlarına } \\
\text { bağlı }\end{array}$ \\
\hline 2 & $\begin{array}{l}\text { Ürüne hemen bitişik çevresel } \\
\text { temas yüzeyleri, örneğin ekipman } \\
\text { çerçevesi, destekleri, tünellerin } \\
\text { veya dolum kabinlerinin dısı, } \\
\text { dolum ekipmanlarının altı, } \\
\text { kontrol panellerinde, motor } \\
\text { gövdelerinde, iskelelerde, } \\
\text { kantarlarda, } \\
\text { Bölge 1 yüzeylerinin yakınındaki } \\
\text { drenajlar. }\end{array}$ & Salmonella & Haftalık & $10-15$ \\
\hline 3 & $\begin{array}{lr}\text { Üründen uzak açik ürün } \\
\text { alanlarındaki temas } & \text { yüzeyleri, } \\
\text { Örneğin el arabalar1, } & \text { forkliftler, } \\
\text { duvarlar, } & \text { kanallar, } \\
\text { kanalizasyonlar, } & \text { zeminler, } \\
\text { tavanlar vb. } & \end{array}$ & Salmonella & Haftalık & $10-15$ \\
\hline 4 & $\begin{array}{l}\text { İşleme alanından uzak alanlar, } \\
\text { örneğin depolar, banyolar, } \\
\text { soyunma odaları, bakım alanları, } \\
\text { kafeterya/mola odaları vb. }\end{array}$ & Salmonella & Aylik & $5-10$ \\
\hline
\end{tabular}

${ }^{1}$ Gerekli durumlarda bölge başına belirlenenden daha fazla numune alınabilmektedir.

Çizelge 6. Çevresel izleme programı ve numune alma planı örneği

\begin{tabular}{|c|c|c|c|}
\hline Bölge Numaras1 & Numune Yeri & Test Siklı̆̆1 & Mikroorganizmalar \\
\hline Bölge 1 & $\begin{array}{l}\text { Karıştırıcilar, konveyörler, } \\
\text { alet-ekipman, üretim masaları } \\
\text { vb. }\end{array}$ & Haftalık & $\begin{array}{l}\text { Toplam Canlı Bakteri (TCB), } \\
\text { koliform, maya ve küf } \\
\text { Enterobacteriaceae. }\end{array}$ \\
\hline Bölge 2 & $\begin{array}{l}\text { Ekipman çerçevesi, bakım } \\
\text { aletleri, damlama kalkanları, } \\
\text { muhafazalar, vb. }\end{array}$ & Haftalık & $\begin{array}{l}\text { TCB, koliform, maya ve küf, } \\
\text { Enterobacteriaceae, Listeria spp. ve } \\
\text { Salmonella spp. }\end{array}$ \\
\hline Bölge 3 & $\begin{array}{l}\text { Duvarlar, } \\
\text { kanalizasyon, } \\
\text { havalandirmalar vb. }\end{array}$ & Haftalık & $\begin{array}{l}\text { TCB, koliform, maya ve küf, } \\
\text { Listeria spp ve Salmonella spp. }\end{array}$ \\
\hline Bölge 4 & $\begin{array}{l}\text { Ofis alanları, soyunma } \\
\text { odaları, bakım odası vb. }\end{array}$ & Aylik & $\begin{array}{l}\text { TCB, koliform, maya ve küf, } \\
\text { Enterobacteriaceae, Listeria spp. ve } \\
\text { Salmonella spp. }\end{array}$ \\
\hline
\end{tabular}


Çevresel analiz sonuçları mikrobiyoloji sorumlusu tarafindan raporlanmalı ve çevresel izlemeden sorumlu ekip tarafindan belirlenen limitler kapsaminda yorumlanmalıdır (Zoellner, vd., 2018). Genellikle patojen belirleme için alınan sürüntü sonuçları zenginleştirme adımlarından sonra pozitif veya negatif olarak rapor edilir (Spanu ve Jordan, 2020). Belirli bir yüzeydeki indikatör mikroorganizmalar sayllırken, ISO 7218:2017 standardında belirtildiği gibi hedeflenen mikroorganizma için kullanılan besiyeri ortamı kapsaminda belirli inkübasyon süresi ve sıcaklı̆g1 referans alınır. Sonuçlar $\mathrm{kob} / \mathrm{cm}^{2}$ (koloni oluşturan birim/ numune yüzey alanı) olarak raporlanmaktadır. Analizlerde negatif bir sonucun veya koloni yokluğunun bazen işletmede bu mikroorganizmanın yokluğuna eşit olmadığına ve bunun numune aldığımız yere, tespit sınırlarına, numune miktarına göre değişebileceği gerçeğine dikkat edilmelidir. (Spanu ve Jordan, 2020). Analiz sonuçlarının özellikle patojenler için sürekli negatif çıkması ÇiP programının kontaminasyon kaynaklarının tespit edilmesi noktasinda yeterince sağlam olmamasindan kaynaklanabilmektedir. Bu gibi durumlarda ÇIP programının gözden geçirilmesi, doğrulanması ve değişen riskler kapsamında revize edilmesi gerekmektedir.

\section{Düzeltici ve önleyici faaliyetlerin belirlenmesi} ÇİP analiz sonuçlarında hedef limitlerin aşıldığ ve/veya patojen mikroorganizmaların pozitif çıktı̆̆ belirlendiği durumlarda gıda güvenliğinin sağlanabilmesi için mümkün olan en kısa sürede harekete geçilebileceği düzeltici eylem planları önceden belirlenmelidir. Eylem planları bölgelere ve dolayısıyla risk düzeylerine bağlı olarak değişmektedir. Bu eylem planları; acil düzeltici eylemleri (örneğin, dezenfektanların değiştirilmesi, sterilize etme sıklıklarının değiştirilmesi vb.), uygunsuzluğun kök nedenini ve uygunsuzluğun giderildiğinin doğrulanmasını içermelidir (Almond Board of California, 2009). ÇİP sadece bir izleme program olmakla birlikte mikrobiyel kontaminasyon riskinin tamamen ortadan kaldırılabilmesi için iyi tasarlanmış düzeltici önleyici faaliyetler ile desteklenmesi gerekmektedir. Düzeltici ve önleyici faaliyet prosedürleri genel olarak aşağıda yer alan adımları içermektedir.

1. ÇIP takımı uygunsuz sonuçlar kapsamında acil olarak toplanmalıdır.

2. Güvenli olmayan süreçte üretilen ürün "uygunsuz ürün" olarak tanımlanmalı ve ürüne uygulanacak işlemler (uygun, imha, yeniden işleme), mikrobiyolojik analizler sonuçlandıktan sonra karar verilmelidir.

3. Uygun olamayan bölgeler kök neden analizi için incelenmeli ve kontaminasyon kaynağının belirlenmesi amacıyla yüzeylerden swab örnekleri alınmalidır.

4. Kontaminasyon nedeni tespit edildikten sonra sorunu ortadan kaldıracak düzeltici faaliyetler belirlenmelidir (temizlik kimyasallarının uygunsuzluğu, personelin etkin temizlik yapmaması, kontrollerin yetersizliği, GMP uygulamalarında aksamalar vb.).

5. Düzeltici faaliyetin etkinliğinin izlenmesi için numune/ analiz sıklığ arttırılmalıdır.

6. Negatif veya uygun olan sonuçlar elde edildiğinde uygunsuzluğun tekrar yaşanmaması için gereken önleyici faaliyetler belirlenmelidir (eğitim, yatırımlar vb.).

7. Sonuçlar sistem gerekliğince kayıt altına alınmalıdır.

Her gıda tesisi gıda güvenliğinin amacını ve gerekliliklerini göz önünde bulundurarak risk temelli bir yaklaşımla kendi düzeltici eylem planını oluşturmalıdır. Çınar ve Onbaşı (2018) dondurulmuş meyve ve sebze işletmesinde yaptıkları ÇİP çalışmasında gerçekleştirilen bazı düzeltici faaliyet örnekleri; el y1kama suyunun sicaklığının ayarlanması, kokusu az ve tahriş ediciliği düşük el dezenfektanı temini, temizliğin etkin yapılması için otomatik dozajı köpük sistem kurulumu, alet ve ekipmanların kolay temizlenmesi için revize edilmesi (eğim, çukurların kapatılması vb.) olarak paylaşılmışır.

\section{SONUÇ}

Gıda risk parametreleri mikrobiyolojik olarak değerlendirildiğinde tehlike tanımları günden güne değişmekte ve halk sağlığ1 üzerindeki potansiyel etkileri artmaktadır. Modern gida güvenliği sistemleri bu tehlikeler karşısında 
yetersiz kalmakta ve gida kaynaklı zehirlenmeler hala küresel bir sorun olarak karşımıza çıkmaktadır. ÇİP gıda tesislerindeki hijyen ve sanitasyon uygulamalarının etkinliğini değerlendirmek ve çapraz kontaminasyonu önlemek için değerli bilgiler sunan bir izleme sistemidir. HACCP tabanlı gıda kalitesi ve güvenlik sistemlerine ÇIP sisteminin entegrasyonu sistemlerin etkinliğinin mikrobiyolojik açıdan değerlendirilmesine ve gida güvenliğinin sağlanmasına imkân sunmaktadır. Diğer yandan bu programların tasarımı ve uygulamasına ilişkin literatürde yer alan çalışmaların az olması bu konuda gida sanayinde boşluklara neden olmaktadır.

Günümüzde bu boşlukların giderilmesi ve ÇİP’lerin kurulumunun yaygınlaştırılması adına dünyanın çeşitli bölgelerinde rehberlik belgeleri ve konuyla ilgili araştırma projeleri giderek daha fazla geliştirilmekte ve yaygınlaşmaktadır. $\mathrm{Bu}$ derlemede, literatürde yer alan temel belgelerin, yayınlanan rehberlerin ve çalısmaların sentezi yapılarak 6 aşamalı kurulum metodolojisi önerilmiştir. Mevcut belge gida sektörü için güncel bilimsel veriler ve uygulanabilmesi için rol modeller sunmaktadır.

\section{ÇIKAR ÇATIŞMASI BEYANI}

Yazarlar, bu makale ile ilgili olarak başka kişiler ve/veya kurumlar arasında çıar çatışması olmadığını beyan etmektedir.

\section{YAZAR KATKILARI}

Elif Onbaş1, araştırma fikri ve hipotezinin oluşturulması, yürütülmesi, kaynak taranması ve çalışmanın yazılmasına katkı sağlamıştır. Aycan Cinar, araştırma yönteminin planlanması, denetlenmesi, eleştirel inceleme, yazım ve dil yönüyle düzenlenmesine katkı sağlamıştır. Yazarlar makalenin son halini okumuş ve onaylamışlardır.

\section{KAYNAKLAR}

Adley, C. C., Ryan, M. P. (2016). The nature and extent of foodborne disease. In Antimicrobial food packaging. Academic Press, the UK, pp. 1-10.

Almond Board of California, (2009). Pathogen environmental monitoring program (PEM). https://www.almonds.com/sites/default/files/p em_book.pdf (Accessed: 03.07.2021)

ANSES, (2020). Avis révisé de l'Agence nationale de sécurité sanitaire de l'alimentation,de l'environnement et du travail relatif à la filière de production des préparations en poudre pour nourrissons. (pp. 1-74).

Acciari, V. A., Iannetti, L., Gattuso, A., Sonnessa, M., Scavia, G., Montagna, C., Addente, N., Torresi, M., Zocchi, L., Scattolini, S., Centorame, P., Marfoglia. C., Prencipe, V. A. andGianfranceschi, M. V. (2016). Tracing sources of Listeria contamination in traditional Italian cheese associated with a US outbreak: investigations in Italy. Epidemiol. Infect., 144 (13): 2719-2727.

Beno, S. M., Stasiewicz, M. J., Andrus, A. D., Ralyea, R. D., Kent, D. J., Martin, N. H., Wiedman, M. and Boor, K. J. (2016). Development and validation of pathogen environmental monitoring programs for small cheese processing facilities. J. Food Prot., 79(12): 2095-2106.

Cappitelli, F., Polo, A., Villa, F. (2014). Biofilm formation in food processing environments is still poorly understood and controlled. Food Eng. Rev., 6: 29-42.

Centers for Disease Control and Prevention, (2016). Foodborne germs and illnesses. https://www. cdc. gov/foodsafety/foodborne germs (Accessed: 06.07.2021)

CDC, (2016). Keeping America Safe From Health Threats New And Old. https://www.cdc.gov/media/releases/2016/p12 14-2016-EOY-dpk.html (Accessed: 03.07.2021)

Cinar, A., Onbaş1, E. (2020). Monitoring environmental microbiological safety in a frozen fruit and vegetable plant. Food Sci. Technol. (Campinas), 41: 232-237. DOI: https://doi.org/10.1590/fst.10420.

Channaiah, L. (2013). Environmental monitoring program: an early warning system for microbiological hazards. https://www.aibinternational.com/aibonline_/w ww.aibonline.org/newsletter/Magazine/Nov_D 
ec2013/EPMEarlyWarningHazards.pdf (Accessed: 12.06.2021)

Chapin, T. K., Nightingale, K. K., Worobo, R. W., Wiedmann, M., \& Strawn, L. K. (2014). Geographical and meteorological factors associated with isolation of Listeria species in New York State produce production and natural environments. J. Food Prot., 77(11): 1919-1928. doi.org/10.4315/0362-028X.JFP-14-132.

EFSA-ECDC, (2019). The European Union One Health 2018 Zoonoses Report. EFSA J. 17: 1276.

EN 17141:2020. Cleanrooms and associated controlled environments - Biocontamination control (for final approval prior to publication). https://www.en-standard.eu/bs-en-17141-2020cleanrooms-and-associated-controlledenvironments-biocontamination-control/. (Accessed: 12.06.2021)

FDA. (2017). Draft guidance for industry: Control of Listeria monocytogenes in ready-to-eat foods (FDA-2008-D-0096). https://www.fda.gov/media/102633/download (Accessed 11.05.2021).

FDA, (2021). Recalls, Market Withdrawals, \& Safety https://www.fda.gov/safety/recalls-marketwithdrawals-safety-alerts. (Accessed 02.06.2021).

FIL-IDF. (2020). Processing environment monitoring. https://www.fil-idf.org/wpcontent/uploads/2020/06/IDF-factsheet-

Processing-Environment.pdf

(Accessed 02.06.2021).

Fukushima, K. (2019). Mandatory implementation of HACCP-based food hygiene control. Food Hyg. Safe. Sci., 60(5): 108-111.

Hoffmann, S., Scallan, E. (2017). Epidemiology, cost, and risk analysis of foodborne disease. In Foodborne Diseases, Academic Press, the UK, pp. 1-10.

Hasnan, N. Z. N., Mohd Ramli, S. H. (2020). Modernizing the preparation of the Malaysian mixed rice dish (MRD) with Cook-Chill Central Kitchen and implementation of HACCP. Int. J.
Gastron. Food Sci., 19: 100193. https://doi.org/ 10.1016/j.ijgfs.2019.100193

ISO 7218:2007, (2007). Microbiology of food and animal feeding stuffs - General requirements and guidance for microbiological examinations. https://www.iso.org/standard/64950.html (Accessed 02.06.2021).

ISO 18593:2018, (2018). Microbiology of the food chain - Horizontal methods for surface sampling. https://www.iso.org/standard/ 64950.html (Accessed 02.06.2021).

Jemmi, T., Stephan. R. (2006). Listeria monocytogenes: Food-borne pathogen and hygiene indicator. Rev. Sci. Tech. Oie., 25(2): 571580.

Jones, G., de la Gandara, M. P., Herrera-Leon, L., Herrera-Leon, S., Martinez, C. V., Hureaux-Roy, R., Abdallah, Y., Nisavanh, A., Fabre, L., Renaudat, C., Mossong, J., Mattheus, W., Huard, C., Le Borgne, C. L., Valk. H., Weill, V.X. and Jourdan-Da Silva, N. (2019). Outbreak of Salmonella enterica serotype Poona in infants linked to persistent Salmonella contamination in an infant formula manufacturing facility, France, August 2018 to February 2019. Euro Surveill., 24(13): 1900161.

Jung, J., Bir, C., Widmar, N. O., \& Sayal, P. (2021). Initial Reports of Foodborne Illness Drive More Public Attention Than Do Food Recall Announcements. J. Food Prot., 84(7): 1150-1159.

Kase, J. A., Zhang, G., \& Chen, Y. (2017). Recent foodborne outbreaks in the United States linked to a typical vehicles lessons learned. Curr. Opin. Food Sci., 18: 56-63. http://dx.doi.org/10.1016/ j.cofs.2017.10.014. $</$ jrn $>$

Magdovitz, B. F., Gummalla, S., Thippareddi, H., \& Harrison, M. A. (2020). Evaluating environmental monitoring protocols for Listeria spp. and Listeria monocytogenes in frozen food manufacturing facilities. J. Food Prot., 83(1): 172187.

Mazaheri, T., Cervantes-Huamán, B. R., Bermúdez-Capdevila, M., Ripolles-Avila, C., \& Rodríguez-Jerez, J. J. (2021). Listeria monocytogenes biofilms in the food industry: is 
the current hygiene program sufficient to combat the persistence of the pathogen?. Microorganisms, 9(1): $\quad$ 181. https://doi.org/10.3390/ microorganisms9010181

Moldenhauer, J. E., J. E. Akers, D. R. Ashtekar, J. Christensen, A. M. Cundell, P. DeSantis, M. B. Dolan, R. A. Fry, M. Ganatra, J. L. Gaudet, J. M. Jordan, A. J. Karren, P. Martinez, J. Mateffy, W. R. McCullers, J. A. Nakamatsu, P. J. Noverini, S. J. O’Brien, D. B. Reber, M. S. Rozo, G., Seixas, G., Tin, N. E., Tomoney, F., van der Zanden, A. L., Vellutato, Jr., and R. B. White. (2014). Fundamentals of an environmental monitoring program. Technical report no. 13 (revised). Parenteral Drug Association, Bethesda, MD. https://store.pda.org/TableOfContents/TR13_ TOC.pdf (Accessed 05.06.2021).

Mota, J. D. O., Boue, G., Prevost, H., Maillet, A., Jaffres, E., Maignien, T., ... \& Federighi, M. (2021). Environmental monitoring program to support food microbiological safety and quality in food industries: a scoping review of the research and guidelines. Food Control, 130: 108283. https://doi.org/10.1016/j.foodcont.2021.10828 3

Muhterem-Uyar, M., Dalmasso, M., Bolocan, A. S., Hernandez, M., Kapetanakou, A. E., Kuchta, T., Manios, S. G., Melero, B., Minarovicovaa, J., Nicolau, A. I., Rovira, J., Skandamis, P. N., Jordan, K., Rodriguez-Lazaro, D., Stessl, B., \& Wagner, M. (2015). Environmental sampling for Listeria monocytogenes control in food processing facilities reveals three contamination scenarios. Food Control, 51: 94-107. https://doi.org/10.1016/j.foodcont.2014.10.042

National Fisheries Institute, (2018). Ready-to-eat seafood pathogen control manual. Virginia, USA: https://www.aboutseafood.com/wpcontent/uploads/2018/04/RTE-Manual-

Second-edition-April-2018.pdf 13.06.2021).

Oliver, S.P. (2019). Foodborne pathogens and disease special issue on the national and international PulseNet network. Foodborne Pathog. Dis., 16(7): 439-440.
Onbaş1, E. (2020). Keşkül üretiminde HACCP sistemi ve Çevresel İzleme Programının (ÇİP) uygulanmas1. Bursa Teknik Üniversitesi Fen Bilimleri Enstitüsü Gıda Mühendisliği Anabilim Dalı Yüksek Lisans Tezi, Bursa, Türkiye, 137 s.

Onmaz, N.E., Karadal, F., Hizlısoy, H. (2016). Gıda Güvenliği Açısından İndikatör Mikroorganizmalar. Turkiye Klinikleri J. Food Hyg. Tecbnol., 2(3): 64-8.

Özdemir, H. (2018). Ürün geri çağırma tüketicileri nasıl etkiler? Marka imajı ve satın alma davranışı üzerine bir araştırma. Third Sect. Rev., 53(3): 11981208.

Panghal, A., Chhikara, N., Sindhu, N., \& Jaglan, S. (2018). Role of food safety management systems in safe food production: A review. J. Food Saf., 38(4): e12464. https://doi.org/10.1111/ jfs. 12464

Rodríguez-Marval, M., Kendall, P.A., Belk, K.E., Sofos, J.N., (2010). Inactivation of Listeria monocytogenes during reheating of frankfurters with hot water before consumption. Food Prot. Trends. 30: 16e24. http://dx.doi.org/10.4315/ 0362-028X-67.2.295

Russo, E. T., Biggerstaff, G., Hoekstra, R. M., Meyer, S., Patel, N., Miller, B., Quick, R. and Salmonella Agona Outbreak Investigation Team. (2013). A recurrent, multistate outbreak of Salmonella serotype Agona infections associated with dry, unsweetened cereal consumption, United States, 2008. J. Food Prot., 76(2): 227-230. https://doi.org/10.4315/0362-028X.JFP-12-209

Simmons, C. K., Wiedmann, M. (2018). Identification and classification of sampling sites for pathogen environmental monitoring programs for Listeria monocytogenes: Results from an expert elicitation. Food Microbiol., 75: 2-17.

Smith, A. M., Tau, N. P., Smouse, S. L., Allam, M., Ismail, A., Ramalwa, N. R., Disenyeng, B., Ngomane, M and Thomas, J. (2019). Outbreak of Listeria monocytogenes in South Africa, 2017 2018: laboratory activities and experiences associated with whole-genome sequencing analysis of isolates. Foodborne Pathog. Dis, 16(7): 524-530. 
Spanu, C., \& Jordan, K. (2020). Listeria monocytogenes environmental sampling program in ready-to-eat processing facilities: A practical approach. Compr. Rev. Food Sci. Food Saf., 19(6): 2843-2861.

Swaminathan, B., \& Gerner-Smidt, P. (2007). The epidemiology of human listeriosis. Microb. Infect., 9: 1236-1243.

Thomas, J., Govender, N., McCarthy, K. M., Erasmus, L. K., Doyle, T. J., Allam, M., Ismail, A., Ramalwa, N., Sekwadi, P., Ntshoe, G., Shonhiwa, A., Essel, V., Tau, N., Smouse, S., Ngomane, H. M., Disenyeng, B., Page, N. A., Govender, N. P., Duse, A. G., Stewart, R., Thomas, T., Mahoney, D., Tourdjman, M., Disson, O., Thouvenot, P., Maury, M. M., Leclercq, A., Lecuit, M., Smith, A. M., \& Blumberg, L. H. (2020). Outbreak of Listeriosis in South Africa Associated with Processed Meat. NEJM., 382(7): 632-643.

United Fresh Produce Association, (2018). Guidance on environmental monitoring and control of Listeria for the fresh produce industry second education. Washington: United Fresh Produce

Association.https://www.centerforproducesafet y.org/amass/documents/document/263/Listeri aGuidanceUFPA2013.pdf (Accessed 17.06.2021).

U.S. Food and Drug Administration- FDA. (2015). FSMA final rule for preventive controls for human food. Current good manufacturing practice and hazard analysis and risk-based preventive controls for human food. Maryland: FDA. https://www.fda.gov/food/food-safetymodernization-act-fsma/fsma-final-rule- preventive-controls-human-food

(Accessed 13.06.2021).

3M, \& Cornell University. (2019). Environmental monitoring handbook for the food and beverage industries. USA:

$3 \mathrm{M}$. https://multimedia.3m.com/mws/media/16845 75O/environmental-monitoring-handbook.pdf (Accessed 10.06.2021).

Weigel, G. (2019). The true costs of food recalls. Smart sense food safety. Retrieved from: https://blog.smartsense.co/costs-of-food-recalls (Accessed 10.06.2021).

WHO. (2015). WHO Estimates of the global burden of foodborne diseases. https://apps.who.int/iris/bitstream/handle/106 65/199350/9789241565165_eng.pdf (Accessed 13.06.2021).

World Health Organisation (WHO, 2020). Available online: https://www.who.int/newsroom/fact-sheets/detail/food-safety (Accessed 13.06.2021).

Zacharski, K. A., Southern, M., Ryan, A., \& Adley, C. C. (2018). Evaluation of an environmental monitoring program for the microbial safety of air and surfaces in a dairy plant environment. J. Food Prot., 81: 1108-1116.

Zoellner, C., Ceres, K., Ghezzi-Kopel, K., Wiedmann, M., \& Ivanek, R. (2018). Design elements of Listeria environmental monitoring programs in food processing facilities: A scoping review of research and guidance materials. Compr. Rev. Food Sci. Food Saf, 17(5): 1156-1171. 